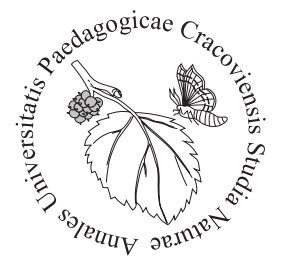

Vendula Kuchařová1* ${ }^{\star}$ Ondřej Daněk ${ }^{1}$, Miša Škorič², Ivana Veselá ${ }^{1}$, Jaroslava Tomenendálová1

${ }^{1}$ Department of Physiology, University of Veterinary and Pharmaceutical Sciences, Brno, Czechia, ${ }^{\star}$ kucharova.vendula@gmail.com ${ }^{2}$ Department of Pathological Morphology and Parasitology, University of Veterinary and Pharmaceutical Sciences Brno, Czechia

\title{
Organ toxicity of diethylnitrosamine and capsaicin in mice - in vivo study
}

\section{Introduction}

Application of diethylnitrosamine (DEN) is commonly used in chemically induced animal models for hepatotoxicity and hepatocarcinogenesis. DEN belongs to a wide range of nitrosamines, substances well known for their general toxic properties. Already in the 1930s, Freund (1937) described the hepatotoxic effect of one of these substances, dimethylnitrosamine. Application of DEN in different doses and regimes was shown to induce histopathological changes in liver and kidneys affecting the biochemical parameters of hepatic injury (Rezaie et al., 2013; Paula-Santos et al., 2014; Cho et al., 2016; Shaker et al., 2016).

Capsaicin (CAP) is the main pungent principle in Capsicum fruit, whose physical and chemical properties and biological effects have been already described and summarised more than 30 years ago (Monsereenusorn et al., 1982). In more recent articles, various biological activities are described, such as thermogenic and weight reducing, analgesic, antioxidant, anti-inflammatory, hypocholesterolemic and hypolipidemic, anti-diabetic, anti-ulcer, anti-apoptotic, and anti-cancer (Basith et al., 2016; Srinivasan, 2016). However, the last-mentioned effect is still controversial. Some authors highlighted a possible dual effect of CAP in mutagenicity and tumorigenicity (Surh, Lee, 1996; Bode, Dong, 2011). Bley et al. (2012) highlight the source and method of extraction of CAP and other capsaicinoid compounds which may have several impurities responsible for the potentially carcinogenicity effect. However, pure CAP is a rather chemopreventive substance according to their study (Bley et al., 2012).

The aim of our study was to assess the toxicity of DEN and CAP in mice liver and kidney and to evaluate the chemoprotective effect of CAP on DEN induced liver and kidney injury. 
Chemicals

Diethylnitrosamine (DEN, Sigma-Aldrich) was dissolved in saline solution $(0.9 \%$ $\mathrm{NaCl}$ ). Capsaicin (CAP, Merck Millipore) was first dissolved in ethanol to a stock solution, and this was further dissolved in saline to form a final solution containing 0.1 CAP in $1 \mathrm{ml}$ 1\% ethanol solution (dosage $1.5 \mathrm{mg} / \mathrm{kg}$ body weight) or a final solution containing $0.05 \mathrm{mg}$ CAP in $1 \mathrm{ml} 1 \%$ ethanol solution (dosage $0.75 \mathrm{mg} / \mathrm{kg}$ body weight).

\section{Animals and experimental conditions}

51 female ICR mice at 4 weeks of age (13-16 g) were obtained from AnLab s.r.o. (Prague, Czech Republic). After 2 weeks of quarantine and acclimatisation, mice were randomly divided into five groups, housed in plastic cages with sawdust as bedding with a 12-h light/dark cycle, and temperature and humidity were monitored twice a day. Drinking water and a standard mouse diet (Biokron s.r.o., Blučina, Czech Republic) was provided ad libitum throughout the experiment.

All experimental procedures were conducted according to the Czech animal welfare protection legal guidelines and EU directives. Paper rolls were used to provide environmental enrichment.

\section{Experimental design and sample collection}

A total of 51 female ICR mice were randomly divided into five groups. Mice from the first group (control, $\mathrm{n}=11$ ) received the ethanol solution ( $1 \%$ ) intraperitoneally (IP) in weeks 3,5,7, 9, and 11 . Mice in the second group (CAP, $\mathrm{n}=10$ ) received CAP IP at a dose of $1.5 \mathrm{mg} / \mathrm{kg}$ body weight (bw) in weeks 3 and 5 and due to impaired tolerance the dose was halved in weeks 7, 9, and $11(0.75 \mathrm{mg} / \mathrm{kg}$ bw). Third group (DEN-CAP, $\mathrm{n}=10$ ) DEN IP at a dose of $25 \mathrm{mg} / \mathrm{kg}$ bw was administered in week 2 and from week 3 until the end of the experiment as in the second group (CAP). Mice in the fourth group (CAP-DEN, $\mathrm{n}=10$ ) received CAP IP at a dose of $1.5 \mathrm{mg} / \mathrm{kg}$ bw in week 1 and a week after DEN IP at a dose $25 \mathrm{mg} / \mathrm{kg}$ bw. In weeks 3, 5, 7, 9, and 11, IP saline was administered. Mice in the last group (DEN, $\mathrm{n}=10$ ) received DEN IP at a dose of $25 \mathrm{mg} /$ $\mathrm{kg}$ bw in week 2 and in weeks 3, 5, 7, 9, and 11 saline IP. All procedures and applications were performed between 8 and 12 hours, and 24 hours after the last application all mice were euthanized using ether overdose and decapitation.

Throughout the experiment, animals were observed daily to assess their general health, and the body weight was measured weekly. After euthanization, blood was collected from each mouse and clotting serum was obtained. Complete necropsy was performed, and the livers and kidneys were weighed, examined macroscopically, fixed 
in $10 \%$ buffered formalin, and representative parts were embedded in paraffin wax.

Biochemical parameters assessment and histological evaluation Total serum protein (TP), albumin (Alb), and activities of alanine aminotransferase (ALT) and aspartate aminotransferase (AST) were assessed by a clinical chemistry analyser, Abbott ARCHITECT c4000 (Abbott, Abbott Park, Illinois, U.S.A.).

Tissue sections of $4 \mu \mathrm{m}$ were processed and routinely stained with haematoxylins and eosin (H\&E). Slides were observed under light microscopy by different experienced histopathologists in a blind fashion and results were compared.

Statistical analysis

Numerical data was statistically processed by MedCalc for Windows, version 15.11.0 (MedCalc Software, Ostend, Belgium). ANOVA and Student t-tests were used.

\section{Results}

There was no statistically significant difference in body and organ weight between control and experimental groups (data not shown). Levels of ALT, AST activity, total protein, and albumin concentration were not statistically different among control and experimental groups (Tab. 1).

Tab. 1. Results of biochemical parameters: TP - total serum protein, Alb - albumin, ALT - alanine aminotransferase, AST - aspartate aminotransferase; values shown as mean $\pm \mathrm{SD}$

\begin{tabular}{lcccc}
\hline Group & TP $[\mathrm{g} / \mathrm{l}]$ & $\mathrm{Alb}[\mathrm{g} / \mathrm{l}]$ & ALT $[\mu \mathrm{kat} / \mathrm{l}]$ & AST $[\mu \mathrm{kat} / \mathrm{l}]$ \\
\hline Control & $54.48 \pm 2.03$ & $38.92 \pm 1.76$ & $0.37 \pm 0.13$ & $2.43 \pm 0.72$ \\
CAP & $52.07 \pm 1.57$ & $37.23 \pm 1.78$ & $0.36 \pm 0.08$ & $1.95 \pm 0.48$ \\
CAP-DEN & $54.57 \pm 3.21$ & $38.33 \pm 2.69$ & $0.35 \pm 0.12$ & $2.43 \pm 0.76$ \\
DEN-CAP & $53.90 \pm 2.85$ & $38.56 \pm 2.58$ & $0.32 \pm 0.08$ & $2.01 \pm 0.48$ \\
DEN & $53.65 \pm 3.92$ & $37.77 \pm 3.36$ & $0.35 \pm 0.10$ & $2.37 \pm 0.50$ \\
\hline
\end{tabular}

The histopathological examination of the liver revealed multifocal lymphoplasmacytic reaction in parenchyma in the DEN treated group (Fig. 1). CAP used as both preventive and therapeutic agent caused a reduction in the number and extent of lesions. In the CAP group, mitotic figures were found suggesting xenobiotic-induced hepatotoxicity or regenerative changes (Fig. 2). In the kidneys, DEN also revealed multifocal lymphoplasmacytic reactions (Fig. 3) that have been mitigated by CAP. Moreover, histopathological observation of the kidney in the DEN group has revealed granular dystrophy of the renal tubules (Fig. 4), which has not been presented in CAP treated mice. In the control group, histological changes were observed neither in the liver nor in the kidneys. 

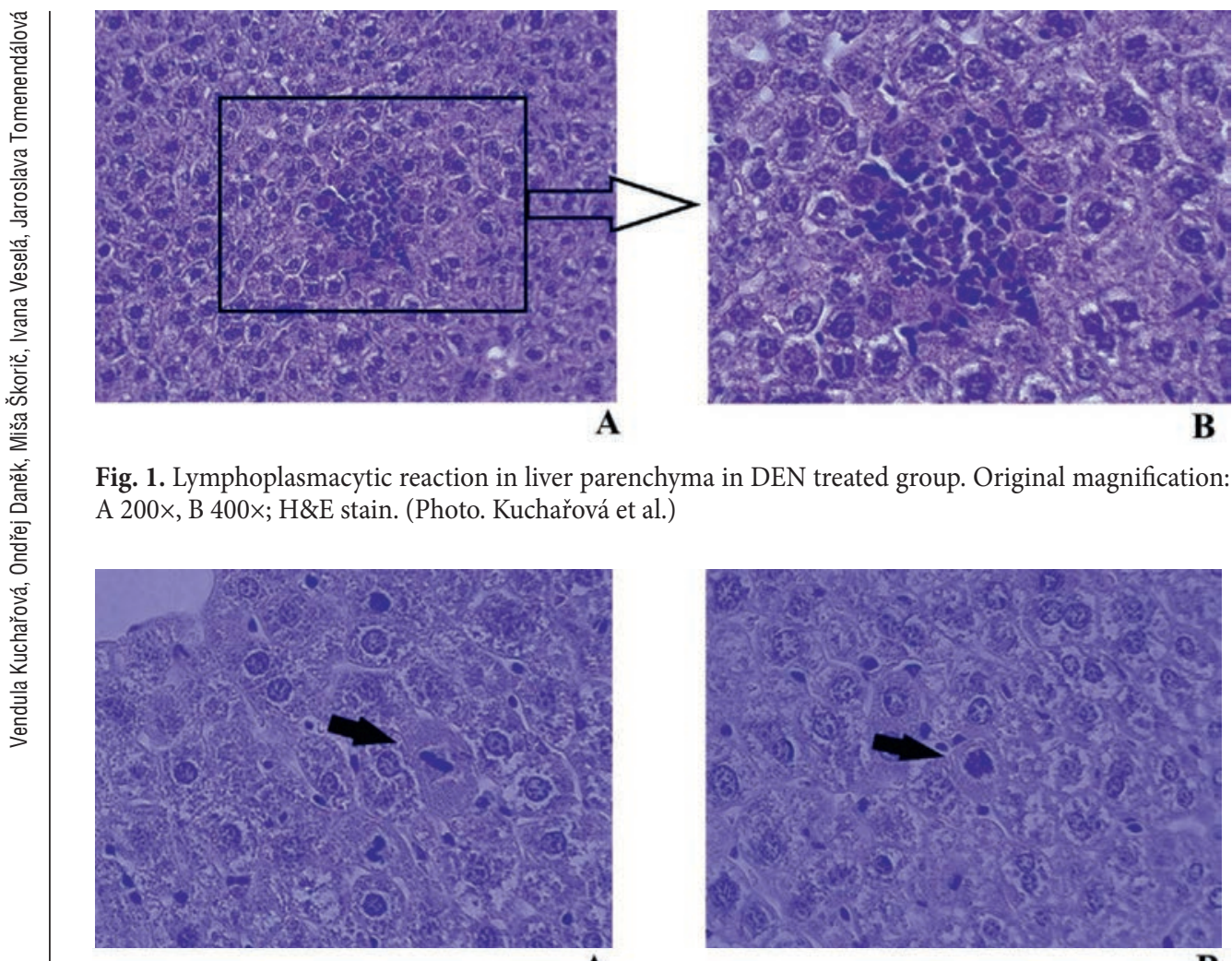

A

B

$\mathbf{A}$

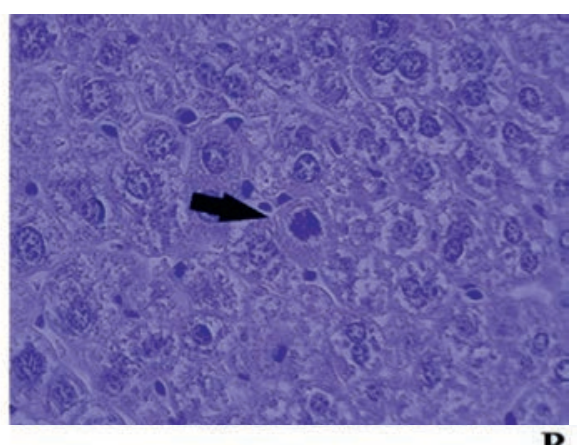

Fig. 2. Mitotic figures in liver parenchyma in CAP treated group. Original magnification: 400x; H\&E stain. (Photo. Kuchařová et al.)

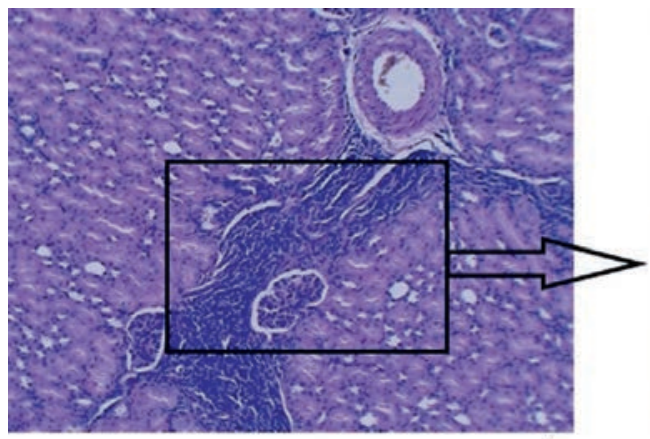

A

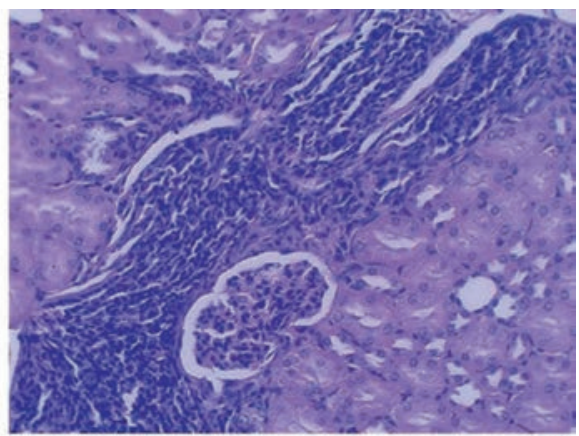

B

Fig. 3. Lymphoplasmacytic reaction in the renal cortex in DEN treated group. Original magnification: A 100x, B 200x; H\&E stain (Photo. Kuchařová et al.) 


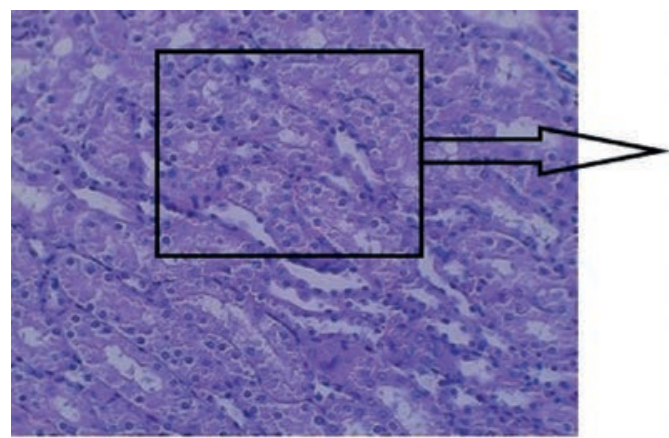

A

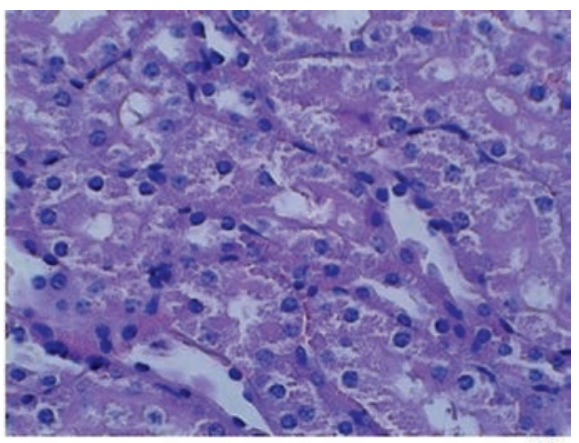

B

Fig. 4. Granular dystrophy of the renal tubules in DEN treated group. Original magnification: A 200x, B 400x; H\&E stain (Photo. Kuchařová et al.)

Discussion

Intraperitoneal application of DEN to adult mice led to increased ALT and AST activities during the first 24 or 48 hours, suggesting a physiologic reaction to the acute toxicity of this chemical (Cho et al., 2016; Hanna et al., 2016; Shaker et al., 2016). When these parameters were assessed after a longer period after DEN application (20 or 40 weeks), the effect was not so prominent. Sun et al. (2012) described increased ALT activity after DEN-initiated and phenobarbital-promoted liver injury with no change in AST activity. However, Healy et al. (2016) did not observe any change in ALT activity after DEN application in female C57BL/6N mice. In our study, we did not find any DEN-induced changes in ALT and AST activity, which was probably caused due to the late sampling after DEN application (11 weeks after DEN administration).

Capsaicin alone does not produce any changes in AST or ALT activity, which is consistent with our results (Hassan et al., 2012; Bitencourt et al., 2015). In both studies, the effect of CAP on carbon tetrachloride $\left(\mathrm{CCl}_{4}\right)$-induced hepatotoxicity was investigated with discordant results. Hassan et al. (2012) found a significant decrease of $\mathrm{CCl}_{4}$-induced elevation of these marker levels in rats, while Bitencourt et al. (2015) observed further elevation of liver enzyme activities when CAP was administered in mice. In more recent studies, the hepatoprotective effect of CAP on alcohol or 'high fat diet' induced liver injury in mice was described (Koneru et al., 2018; Şekeroğlu et al., 2018). Since we have not shown any effect of DEN on liver enzyme activity, we cannot assess the protective or harmful effects of CAP.

Time-related DEN-induced histological changes were described in detail by Paula-Santos et al. (2014). The duration of our experiment allowed the development of only early toxic lesions, and a longer time is needed for proliferative, dysplastic, or neoplastic lesions to development. Mohammed et al. (2014) used 
CAP as a preventive and therapeutic agent against DEN-induced liver injury and hepatocellular carcinoma in rats with a prominent beneficial effect of CAP on liver histology, which is consistent with our results.

The renal toxicity of DEN was described by Rezaie et al. (2013) with signs of acute tubular necrosis in histological sections. Our results confirm DEN-nephrotoxicity with the promising beneficial effect of CAP.

\section{Conclusions}

In this study, a mild protective effect of CAP on DEN-induced hepatotoxicity and nephrotoxicity was shown only in histopathological changes. The toxicity of CAP itself is questionable, and further studies should be performed to verify its chemopreventive potential.

\section{Acknowledgement}

This study was supported by grant IGA VFU Brno 114/2016/FVL.

\section{References}

Basith, S., Cui, M., Hong, S., Choi, S. (2016). Harnessing the therapeutic potential of capsaicin and its analogues in pain and other diseases. Molecules, 21(8), E966. DOI: 10.3390/molecules21080966

Bitencourt, S., Stradiot, L., Verhulst, S., Thoen, L., Mannaerts, I., van Grunsven, L.A. (2015). Inhibitory effect of dietary capsaicin on liver fibrosis in mice. Molecular Nutrition \& Food Research, 59(6), 1107-1116. DOI: $10.1002 / \mathrm{mnfr} .201400649$

Bley, K., Boorman, G., Mohammad, B., McKenzie, D., Babbar, S. (2012). A comprehensive review of the carcinogenic and anticarcinogenic potential of capsaicin. Toxicologic Pathology, 40(6), 847-873. DOI: $10.1177 / 0192623312444471$

Bode, A.M., Dong, Z. (2011). The two faces of capsaicin. Cancer Research, 71(8), 2809-2814. DOI: 10.1158/0008-5472.CAN-10-3756

Cho, J.M., Kim, K.Y., Ji, S.D., Kim, E.H. (2016). Protective effect of boiled and freeze-dried mature silkworm larval powder against diethylnitrosamine-induced hepatotoxicity in mice. Journal of Cancer Prevention, 21(3), 173-181. DOI: 10.15430/JCP.2016.21.3.173

Freund, H.A. (1937). Clinical manifestation and studies in parenchymatous hepatitis. Annals of Internal Medicine, 10(8), 1144-1155. DOI: 10.7326/0003-4819-10-8-1144

Hanna, D., Riedmaier, A.E., Sugamori, K.S., Grant, D.M. (2016). Influence of sex and developmental stage on acute hepatotoxic and inflammatory responses to liver procarcinogens in the mouse. Toxicology, 373, 30-40. DOI: 10.1016/j.tox.2016.10.006

Hassan, M.H., Edfawy, M., Mansour, A., Hamed, A.A. (2012). Antioxidant and antiapoptotic effects of capsaicin against carbon tetrachloride-induced hepatotoxicity in rats. Toxicology and Industrial Health, 28(5), 428-438. DOI: 10.1177/0748233711413801

Healy, M.E., Lahiri, S., Hargett, S.R., Chow, J.D., Byrne, F.L., Breen, D.S., Kenwood, B.M., Taddeo, E.P., Lackner, C., Caldwell, S.H., Hoehn, K.L. (2016). Dietary sugar intake increases liver tumor incidence in female mice. Scientific Reports, 6, 22292. DOI: 10.1038/srep22292

Koneru, M., Sahu, B.D., Mir, S.M., Ravuri, H.G., Kuncha, M., Mahesh Kumar, J., Kilari, E.K., Sistla, R. (2018). Capsaicin, the pungent principle of peppers, ameliorates alcohol-induced acute liver injury in 
mice via modulation of matrix metalloproteinases. Canadian Journal of Physiology and Pharmacology, 96(4), 419-427. DOI: 10.1139/cjpp-2017-0473

Mohammed, F.Z., Sultan, A.S., Abas, A.M. (2014). Chemopreventive and therapeutic effect of capsaicin against diethylnitrosamine induced liver injury and hepatocellular carcinoma in rats. International Journal of Biological \& Pharmaceutical Research, 5(8), 630-642

Monsereenusorn, Y., Kongsamut, S., Pezalla, P.D. (1982). Capsaicin-a literature survey. Critical Reviews in Toxicology, 10(4), 321-339. DOI: 10.3109/10408448209003371

Paula-Santos, N., Colaço, A., Da Costa, R.M.G., Oliveira, M.M., Peixoto, F., Oliveira, P.A. (2014). N-diethylnitrosamine mouse hepatotoxicity: time-related effects on histology and oxidative stress. Experimental and Toxicologic Pathology, 66(9-10), 429-436. DOI: 10.1016/j.etp.2014.07.002

Rezaie, A., Fazlara, A., Haghi Karamolah, M., Shahriari, A., Najaf Zadeh, H., Pashmforosh, M. (2013). Effects of Echinacea purpurea on hepatic and renal toxicity induced by diethylnitrosamine in rats. Jundishapur Journal of Natural Pharmaceutical Products, 8(2), 60-64. DOI: 10.5812/jjnpp.9686

Şekeroğlu, V., Aydın, B., Atlı Şekeroğlu, Z., Özdener Kömpe, Y. (2018). Hepatoprotective effects of capsaicin and alpha-tocopherol on mitochondrial function in mice fed a high-fat diet. Biomedicine \& Pharmacotherapy, 98, 821-825. DOI: 10.1016/j.biopha.2018.01.026

Shaker, M.E., Ashamallah, S.A., El-Mesery, M. (2016). The novel c-Met inhibitor capmatinib mitigates diethylnitrosamine acute liver injury in mice. Toxicology Letters, 261, 13-25. DOI: 10.1016/j.toxlet.2016.08.015

Srinivasan, K. (2016). Biological activities of red pepper (Capsicum annuum) and its pungent principle capsaicin: A Review. Critical Reviews in Food Science and Nutrition, 56(9), 1488-500. DOI: $10.1080 / 10408398.2013 .772090$

Sun, H., Yu, L., Wei, H., Liu, G. (2012). A novel antihepatitis drug, bicyclol, prevents liver carcinogenesis in diethylnitrosamine-initiated and phenobarbital-promoted mice tumor model. Journal of Biomedicine and Biotechnology, 2012, 584728. DOI: 10.1155/2012/584728

Surh, Y.J., Lee, S.S. (1996). Capsaicin in hot chili pepper: carcinogen, co-carcinogen or anticarcinogen? Food and Chemical Toxicology, 34(3), 313-316. DOI: 10.1016/0278-6915(95)00108-5

\section{Abstract}

Diethylnitrosamine (DEN) is proven to be toxic to kidneys and liver and to act as a potent carcinogen mainly in liver. Capsaicin (CAP) is an alkaloid produced by Capsicum genus plants and is considered to be a protective agent against the toxicity and carcinogenicity of many substances including DEN. The aim of this study was to assess the toxicity of DEN and CAP in the livers and kidneys in mice. The experiment started after two weeks of acclimatisation and was conducted according to the Czech animal welfare protection legal guidelines. At the end of the experiment, the mice were euthanized and the toxicity of DEN and CAP in the livers and kidneys were analysed. The histopathological examination of the livers revealed multifocal lymphoplasmacytic reaction in parenchyma in the DEN treated group. CAP used as both a preventive and therapeutic agent caused a reduction in the number and extent of lesions. In the CAP group, mitotic figures were found, indicating xenobiotic-induced hepatotoxicity or regenerative changes. In the kidneys, DEN also revealed multifocal lymphoplasmacytic reactions that have been mitigated by CAP. Moreover, histopathological observation of the kidneys in the DEN group revealed granular dystrophy of the renal tubules, which were not presented in CAP treated mice. Levels of ALT, AST activity, total protein, and albumin concentrations were not statistically different among control and experimental groups. In this study, the mild protective effect of CAP on DEN-induced hepatotoxicity and nephrotoxicity was shown only in histopathological changes. The toxicity of CAP itself is questionable, and further studies should be performed to verify its chemopreventive potential.

Key words: capsaicin, diethylnitrosamine, hepatotoxicity, mice, nephrotoxicity

Received: [2018.06.07]

Accepted: [2018.11.21] 


\section{Toksyczność narządowa dietylo-nitrozaminy i kapsaicyny u myszy - badanie in vivo \\ Streszczenie}

Udowodniono, że dietylo-nitrozamina (DEN) działa toksycznie na nerki i wątrobę oraz jako silny czynnik rakotwórczy, głównie w wątrobie. Kapsaicyna (CAP) jest alkaloidem wytwarzanym przez gatunki z rodzaju Capsicum i jest uważana za czynnik ochronny przeciwko toksyczności oraz rakotwórczości wielu substancji, w tym również DEN. Celem tego badania była ocena toksyczności DEN i CAP w wątrobie oraz nerkach myszy. Eksperyment rozpoczął się po dwóch tygodniach aklimatyzacji i został przeprowadzony zgodnie z czeskimi przepisami prawnymi dotyczącymi ochrony zwierząt. Pod koniec doświadczenia myszy uśmiercano, następnie dokonano oceny toksyczności DEN i CAP w wątrobie oraz nerkach. Badanie histopatologiczne wątroby wykazało wieloogniskową reakcję limfoplazmatyczną w miąższu w grupie poddanej działaniu DEN. CAP stosowany jako środek zapobiegawczy i leczniczy powodował zmniejszenie liczby oraz rozmiaru zmian. W grupie poddanej CAP stwierdzono formy mitotyczne wskazujące na hepatotoksyczność wywołaną ksenobiotykami lub też na zmiany regeneracyjne. W nerkach poddanych DEN stwierdzono również wieloogniskową reakcję limfoplazmatyczną, która była łagodzona przez CAP. Ponadto obserwacja histopatologiczna nerki w grupie DEN ujawniła dystrofię ziarnistą kanalików nerkowych, której nie przedstawiono u myszy poddanych CAP. Poziomy aktywności ALT, AST, stężenia białka $\mathrm{i}$ albuminy nie były statystycznie różne $\mathrm{w}$ grupach kontrolnych i eksperymentalnych. $\mathrm{W}$ badaniu tym łagodny ochronny wpływ CAP na indukowaną przez DEN hepatotoksyczność i nefrotoksyczność wykazano tylko w zmianach histopatologicznych. Toksyczność samej CAP jest wątpliwa i należy przeprowadzić dalsze badania w celu zweryfikowania jej potencjału chemoprewencyjnego.

Słowa kluczowe: kapsaicyna, dietylo-nitrozoamina, hepatotoksyczność, myszy, nefrotoksyczność

\section{Information on the authors}

\section{Vendula Kuchařová}

She is a PhD student and assistant at the Department of Physiology at the University of Veterinary and Pharmaceutical Sciences Brno. The topic of her PhD study is The effect of capsaicin on tumour progression - in vivo model.

\section{Ondřej Daněk}

He studies in the Master's Degree Study Programme at the Faculty of Veterinary Medicine at the University of Veterinary and Pharmaceutical Sciences Brno. He is interested in cell biology and animal physiology.

\section{Miša Škorič}

He is an associate professors and leader of the discipline "Pathological Morphology" at the Department of Pathological Morphology and Parasitology at the University of Veterinary and Pharmaceutical Sciences Brno. He is a member of ESVP (European Society of Veterinary Pathologists), and his research activities include the Mycobacterioses of animals, the detection of tissue defects in transplanted pulmonary valve (porcine model), the repair of bone defects, and colorectal anastomoses (rabbit).

\section{Ivana Veselá}

She is an assistant professor at the Department of Physiology at the University of Veterinary and Pharmaceutical Sciences Brno. She is interested mainly in cell biology and natural substances such as aeruginosin-865, resveratrol, and capsaicin in medicine.

\section{Jaroslava Tomenendálová}

She is an assistant professor and leader of the discipline "Pathological Physiology" at the Department of Physiology at the University of Veterinary and Pharmaceutical Sciences Brno. She also focuses on cell biology and natural products, predominantly in cancer prevention and therapy. 